\title{
RICHARD ELLIS, PRINTER
}

\author{
By Earl Schenck Miers
}

A year and a balf ago, in order to stimulate an interest in good printing, four distinguisbed bookmen were brougbt to the University to lecture, and for some days before each one spoke, examples of their work were placed on exbibition in the Library. This winter, as a furtber stimulant to the cause of fine bookmaking, the Library plans a display of the books and miscellanea printed by Richard Ellis. In order to explain sometbing of Mr. Ellis' work, Mr. Miers bas written the following article for The Journal, and reprints of it will be banded to those who visit the Library to see the exbibition.

AM JOHNSON, for all his erudition and wit, occasionally experienced a moment when he came off second best. There was that afternoon when Sam encountered Edwards, an old crony from Oxford, in the years when the great doctor's shuffle had begun to drag more slowly across dusty London byways. Like most grown men who know better but still cannot resist the weakness, these two fell to recalling youthful adventures, each wishing the other would keep quiet.

"We are both old men now," Edwards said sadly.

"We are, sir," Dr. Johnson replied, "but do not let us discourage one another."

Edwards glanced down his long, thin nose. He had practiced law, but the money he had made had been spent or given away.

"It is better to live rich than to die rich," Johnson said.

Edwards' face brightened. He looked at Johnson and his rejoinder has made him immortal:

"You are a philosopher, Dr. Johnson. I have tried, too, in my time to be a philosopher; but, I don't know how, cheerfulness was always breaking in."

Richard Ellis never tried to be a philosopher of the sensible, pragmatic type who believes that a man shall toil eight hours a day at a respectable calling and so become an earnest husband, a good father, and, within modest measure, a breadwinner. Through high school and at George Washington University, at the Smithsonian Institution, and the Bureau of Mines he packed his head full of the lore of physical chemistry, grimly 
resolved to become a metallurgist, but something more than cheerfulness was breaking in to refute the philosophy which had given a scientific turn to bis course in life. There was, in addition, that more diverting nuisance bobbing up when least expected-that confounded inner artist who too frequently wore the same pair of shoes and rumpled the same sleepless pillow. There was no escaping this plaguing rascal who haunted Ellis' dreams, who whispered in his ear that he was not the man for set hours or methodical research, and who told him that he had better quit fooling himself while there was still time. Richard Ellis surrendered. He became a printer.

Some typographic humorist has muttered that printing was born five hundred years ago, practically perfect, and, in a sense, that is true, for the pages which Johann Gutenberg pulled from the presses of Mainz in those rare intervals when he wasn't dodging creditors have a fineness of proportion that is instantly appealing. But in every age since Gutenberg there have been printers who worked for love as well as for profit, who have toiled with the creative urge deep in the marrow of their bones, and who have enriched the craft by their effort.

Printing in America has come of age principally since the turn of the present century. Its beginnings were, to be sure, as romantic as the most zealous patriot could wish them. There was B. Franklin of Philadelphia, the lad who arrived in the citadel of brotherly love with a roll under each arm and a quick eye for the charm of his landlady's daughter; and there was Bartholomew Green, the first printer of Boston who for want of better lodging spent one winter sleeping in a barrel. But while certain twentieth-century printers have not become known for their eccentricities, their work, viewed objectively, is good. Bruce Rogers, Daniel Berkeley Updike, and Frederic W. Goudy form one trio who have tickled destiny's bony rib and drawn an indulgent smile. Theodore L. DeVinne and Walter Gillis are firmly anchored in the history of American printing; and there are others whose work gives promise of endurance. The group, however, is select-make no mistake about that. No one is there by accident, for there can be only one means of admission and that is by performance.

Richard Ellis walks in this select group. By modern standards of "production or bust," he is a horse and buggy printer, 
and proud of the tag; he will guarantee that his meticulous thoroughness will goad any efficiency expert into a fury of despair within a week, the Sabbath excluded; but it is Richard Ellis' "horse and buggy-ness" which, in a very real sense, has brought to modern bookmaking a freshness of perspective, a new richness of achievement. He works in a corner of one of the busiest printing plants in America, where one would least expect to find him. A lesser spirit might have been consumed by the driving pound of roaring presses, the hammer of boards on packing cases, the perpetual appearance of new delivery schedules. But not Richard Ellis. He is that solid, unwavering kind of rugged individualist who can vote for Roosevelt's third term and still saunter into his office at ten in the morning.

\section{II}

The circumstances which led Richard Ellis into printing go back to his boyhood. His father, a lawyer and collector of eighteenth century literature, awakened in the youngster a passion for books and for reading, while his mother, who painted in oils, developed his artistic perceptions-an unerring eye for proportion and color, a sixth sense for knowing when whatever he was creating was "just right." A hand-powered printing press completed the chain of events drawing young Richard toward printing as his life's work. Once he had actually handled type, once the smear of printer's ink was on his hands and face, its smell deep in his nostrils, there was never any real chance of turning back. Typomania is an incurable disease.

Goudy has called type "the voice of today, the herald of tomorrow," and the remark is likely to live as long as any of the distinguished type faces which Goudy has created. Young Richard Ellis, holding a piece of type in his hand, felt immediately this first pulsing thrill which comes to those who work with type-its power so great that, once released five hundred years ago, it altered the course of civilization. But to the student of printing, type becomes something more than a potential weapon. He clutches the metal cube and sees the parade of men who have labored and dreamed and too often died in poverty to make this moment possible-Gutenberg reading the first pages of the Bible which were to astonish the world ... William Caxton, working under the shadow of Westminster 
Abbey, where he produced some eighteen thousand pages, nearly all of folio size . . . Nicholas Jensen, who cut the first Roman letter ... Aldus Manutius of Venice, who gave the world the Italic letter when he published the Satires of Fuvenal and Persius in $\mathrm{I} 5 \mathrm{OI}$. He sees the parade swelling-Plantin, Estienne, Tory and the Elzevirs, Baskerville, Bodoni and William Morris-and his own heartbeat quickens and his eyes grow brighter.

Even during those undergraduate years when Richard Ellis perspired over his physical chemistry and planned to pursue graduate work in metallurgy at M.I.T., he could not make a complete break with printing. His boyhood press never lost its fascination for him, and during summer vacations the influence of understanding friends made it possible for him to work without stipend at the Carnahan Press in Washington, D.C. In I I $^{5}$, at the age of twenty-one, he decided definitely to become a printer, and since even then he was a fair hand at setting type and handling a press, he was employed by the Carnahan Press (this time with pay), where he began learning the business. Here he had his first experience in the designing and printing of private editions which he secured through family contacts.

There came a moment early in the following year which was easily the most important in Ellis's first months of apprenticeship. Like every good bookmaker on a holiday, he was browsing one afternoon in a book store-Lowdermilk's in Washingtonwhen he chanced to pull from the shelves the Riverside edition of Boccaccio's Life of Dante. At once he recognized that here was a book that was distinctly an artistic creation, and turning to the colophon he found the name of Bruce Rogers. In a glance Rogers' work revealed much to the knowing eye-the fine, studied craftsmanship of a traditionalist at heart, the sprightly inventiveness of an alert, exploring mind. Ellis determined to know more of the work of Rogers, this artist-printer who was a prophet to book collectors and printers, and who could be dignified with the mark of genius in spite of Carl Purington Rollins' playful appositive of "America's typographic playboy."

Before the year was out Richard Ellis had acquired many of Bruce Rogers' Riverside Press books. Reading and studying these volumes made him long to own the books of other famous presses, a longing which quickly outstripped his pocketbook. 
Gradually, however, his typographic library grew, including emissions from Goudy's Village Press, the Kelmscott Press of William Morris, the Doves Press, books of William Pickering, who was the great reviver of the use of Caslon's types; and, at the same time, he steeped himself in the work of old masters, particularly those of the seventeenth and eighteenth centuries. But though he became a thorough student of printing from Gutenberg to those pre-war days of 'I 5 and 'I6, his principal indebtedness was to Bruce Rogers. Page by page he studied those Riverside editions, then spent hours experimenting with type, page arrangement, paper, binding. Today, a quarter of a century later, he admits eagerly, "B.R.'s work revealed contemporary fine printing in a new vein-whatever inspiration I had for further study I owe to his books."

The World War interrupted Ellis' printing career. As a chemist he was detailed to poison gas research; and he continued with the Chemical Warfare Service, suffering several gassings, and coming back from this duty with a troubling deafness in one ear. In I9I9 he returned to printing, though, for a while, he embarked on a short flight in advertising and editorial writing; then came an association with Judd and Detweiler in Washington, another with Norman T. A. Munder in Baltimore, and finally, in I923, his northward trek brought him to New York where he was typographical advisor to the Ray D. Lillibridge advertising agency. Through these five years his hands may have been busy with other pursuits, but his heart kept turning back to the love of books and to the memory of the afternoon in Lowdermilk's when he first had scanned the Riverside Boccaccio; soon he had turned from advertising to an association with Everett Currier and The DeVinne Press, and then in 1924 he opened offices at 522 Fifth Avenue and his Georgian Press was launched.

Appropriately, the first printing to carry the Georgian Press imprint (1925) was a broadside written by Henry Stevens, expressing Ellis' credo. The boy who had become enthralled by seventeenth and eighteenth century literature almost from the day he had stopped toddling, and the lad who liked to hold type in his hand and smell the good pungent odor from the ink roller could not have found better words to express his maturing passion for the bookmaker's art than those of Stevens: 
Good taste, skill and severe training are as requisite and necessary in the proper production of books as in any other of the fine arts. The well recognized "lines of beauty" are as essential and well defined in the one case as in the other. Books are both our luxuries and our daily bread. They have become to our lives and happiness prime necessities. They are our trusted favourites, our guardians, our confidential advisors, and the safe consumers of our leisure. They cheer us in poverty and comfort us in the misery of affluence. They absorb the effervescence of impetuous youth and while away the tedium of age. You may not teach ignorance to a youth who carries a favourite book in his pocket; and to a man who masters his appetites a good book is a talisman which insures him against the dangers of overspeed, idleness and shallowness.

For three years Ellis stuck to his New York office, adding materially to his typographic "laboratory" equipment, producing good work even though he was obliged to entrust his presswork to various plants. One of the memorable books of those days, was his edition of Dickens' Cbristmas Carol (1925) which he printed for George A. Ball of Muncie, Indiana.

Still, difficulties arose. There was the incident of six hundred dollars worth of handsome handmade paper with a deckle on the four sides which he shipped to a distant printer with instructions to save the deckle. The printer was an obliging fellow-carefully he trimmed the deckle off the paper and shipped it back to 522 Fifth Avenue. A wicked gleam still kindles in Richard Ellis' eyes as he tells the story.

More than the shortcomings of other craftsmen disturbed the proprietor of the Georgian Press in those early years. Merely to plan books was not enough, and one day near his home in Westport, Connecticut, he saw a barn, large and venerable, and a long cherished dream took hold of him. Mentally he began transforming that barn, seeing the ideal printinghouse emerge. He drew a deep breath and plunged. Six golden years followed.

III

The man who wanted to oversee all the steps in fine bookmaking had the same urge in the remodelling of the old barn in Westport. Ellis was his own architect, and stood over the workmen. Even as the hammers pounded and the saws buzzed he was turning over in his mind the announcement he would compose to explain this great dream: "The Georgian Press is 


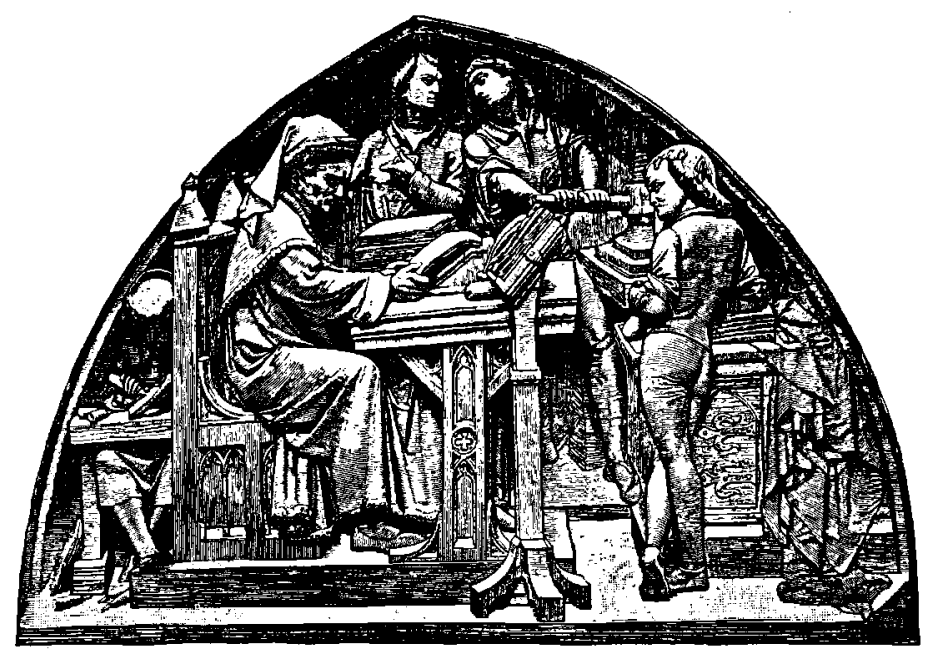

BAS,RELIEF FROM THE ENTABLATURE IN THE JERUSALEM CHAMBER, WESTMINSTER ABBEY

OOD TASTE, SKILL AND SEVERE TRAIN,
ING ARE AS REQUISITE AND NECESSARY
in the proper production of books as in any other of the fine arts. The well recognized "lines of beauty" are as essential and well defined in the one case as in the other. Books are both our luxuries and our daily bread. They have become to our lives and happiness prime necessities. They are our trusted favourites, our guardians, our confidential advis. ers, and the safe consumers of our leisure. They cheer us in poverty and comfort us in the misery of aftluence. They ab, sorb the effervescence of impetuous youth, and while away the tedium of age. You may not teach ignorance to a youth who carries a favourite book in his pocket; and to a man who mas, ters his appetites a good book is a talisman which insures him against the dangers of overspeed, idleness and shallowness. [A broadside written by Henry Stevens and arranged in type by RICHARDW. ELLIS, at the Georgian Press, in the City of NewYork. Two hundred and twenty copies have been printed by this Private Press, in the month of October, MCMXXV]

Facsimile, sligbtly reduced, of the first Georgian Press item. In the original, the initial and last four lines were in red. The type used was Goudy Antique. 
now established in a home congenial to the type of work which it aims to do; in a quiet New England setting, conducive to leisurely, careful craftsmanship." A visitor to the Press entered the Colonial doorway to glimpse, through an arched opening from the entry, the type cabinets, presses, and other equipment of the work shop. Sun streamed into the building through a continuous line of large casement windows, partially shaded by the shrubbery surrounding. The stairs to the left led to the library and the study where on the wood walls were specimens of fine printing from Wynkyn de Worde to William Morris; at one end there was a large open fireplace, at the other a balcony overlooking the presses.

In this printer's paradise Richard Ellis worked on his own schedule which was virtually all the time. An idea would seize him on the way to bed; softly, he would creep down the stairs and off to the barn; and, usually a bit sheepish, he would not reappear until breakfast.

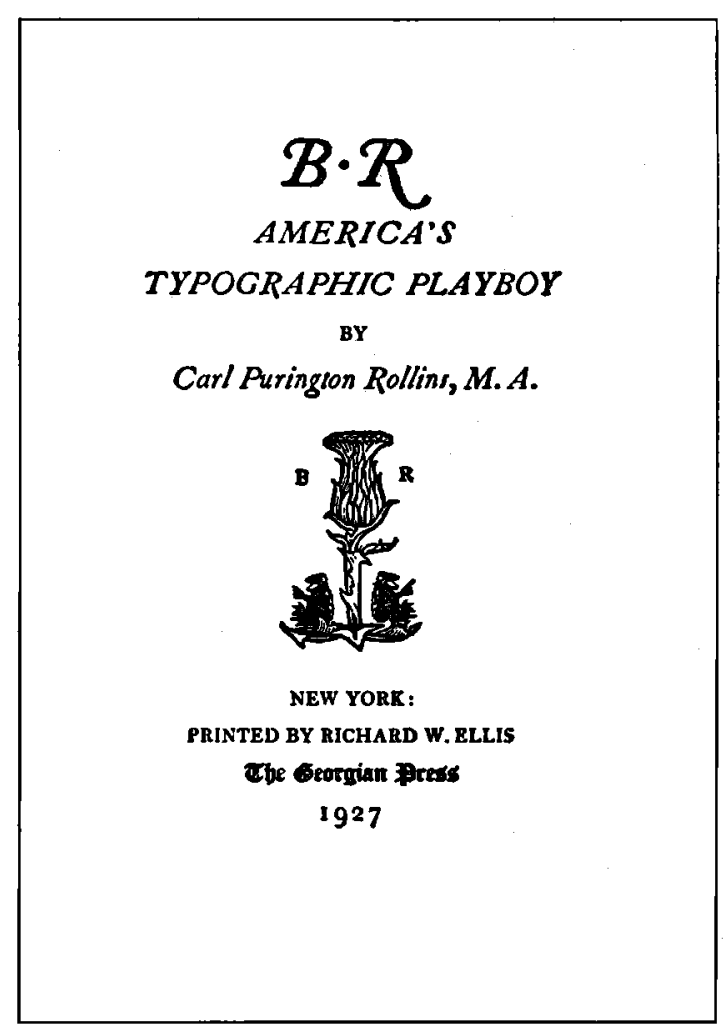

The text is composed in Monotype Scotcb Roman, and printed from type on an Englisb band-made paper. Decoration on title page in green. 
At Westport, Richard Ellis printed some fifty books; a few carried his own imprint of "Richard W. Ellis: The Georgian Press" as publisher, but the majority were produced for publishers and private collectors. Mitchell Kennerley and Colonel Ralph H. Isham were his loyal friends and patrons; Random House, Rimington \& Hooper, and Doubleday, Doran brought him their choice books; all eighteen of the Cheshire House limited editions sponsored by Walter P. Chrysler, Jr. were printed here; Thomas B. Lockwood of Buffalo was another staunch supporter. Over the format, the typographic plan, and its execution Richard Ellis demanded complete jurisdiction; now and then he agreed to submit proofs, even more rarely to send trial pages. If the need arose, he became editor as well as printer, arranging for introductions, forewords and annotations, or writing them himself. This was a high-handed business, but it was justified by one fact: his work was such that collectors still vie for the books which came out of Westport during those golden years.

Tbe text is composed by band in Goudy Kennerley and Old Style italic. Printed from type on an Englisb band-made paper. Decorations on title page in old red.

\section{IS BERNARD SHAW}

\section{a Dramatist?}

A Scientific, but imaginary Symposium in the neo-Socratic Manner: Conduded by Bernard Shaw's Biographer

Archibald Henderson

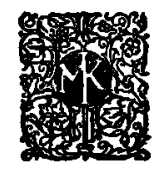

New York E London MITCHELL KENNERLEY 1929 
The best known of his books at Westport is, of course, the Cheshire House edition of The Inferno of Dante Aligbieri, with the seven William Blake engravings here used for the first time. A folio volume, $\mathrm{I} 3 \times 26$ inches, published in a limited edition at sixty dollars, the pages were composed by hand in 22-point Caslon and 22-point Bell italic. Another Westport triumph was The Travells of Capt. Fobn Smith, a small folio volume set by hand in Original Old Style italic and Monotype Garamont and printed in a limited edition of 377 copies for Rimington \& Hooper, publishers. There was also an edition of Shakespeare's Sonnets, set in Original Old Style and Garamond, full bound in red morocco. There was the Rollins's piece on Bruce Rogers published by Ellis, a happy association of three master craftsmen on the one title-page; also, reflecting Ellis' interests in eighteenth century literature, were his reprinting of the very rare essay in English by Voltaire, The History of the Civil Wars of France, and the entrancing pot-boiler of Oliver Goldsmith's early years, The Story of the Cock-Lane Gbost.

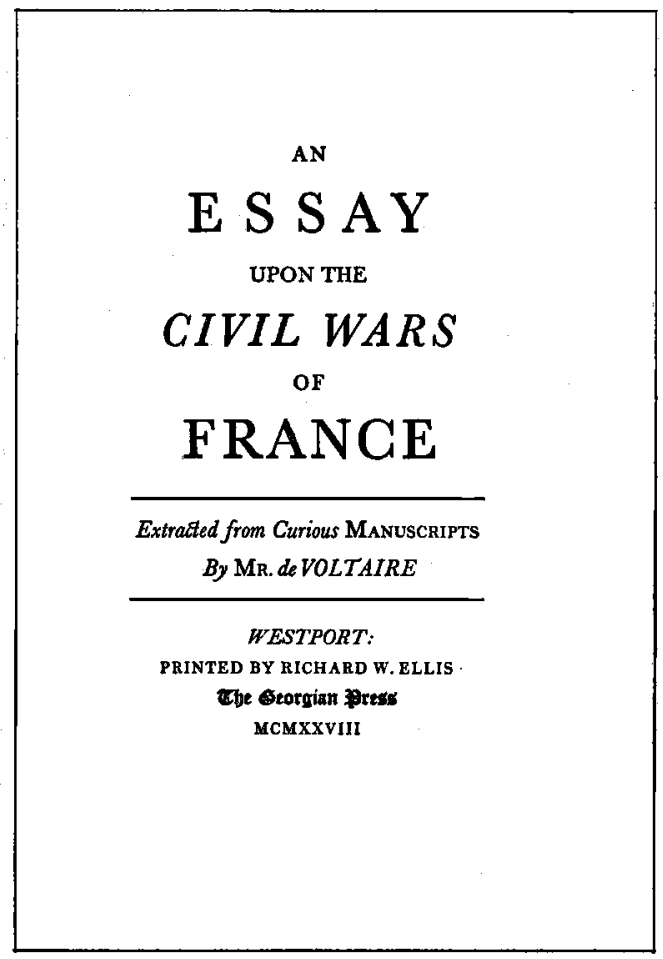

$T$ be text is composed by band in Englisb Baskerville and Old Style italic. Printed from type on an Englisb band-made paper. 
Bookmen, publishers, authors came to rely on Ellis, to nod when he said a book should be thus and so, an introduction revamped or discarded, and happy results flowed from this confidence. Bernard Shaw recognized Ellis as a kindred spirit when the latter was printing some articles by Shaw on Karl Marx and the Jevonian Value Theory. In Shaw's correspondence with Ellis, the author referred to his studies under Philip H. Wicksteed, the well-known economist: "It was this course of study that enabled me to write the criticism of Marx's theory in the National Reformer and to trace the steps by which he was led in to his error when one more step would have enabled him to anticipate Jevons. As Wicksteed's article, my reply, and his rejoinder are in the public domain like the National Reformer articles, I should, in your place, add them to your volume with a brief preface by yourself setting forth the facts from this letter." Shaw was never a man to entrust work to another if he feared his case might suffer from bungling; it was common knowledge in the trade, then and now,

Composed in Monotype Goudy Italian Old Style, and printed from type on a French macbine-made paper. "Zadig" and decoration on title page in terra-cotta red.

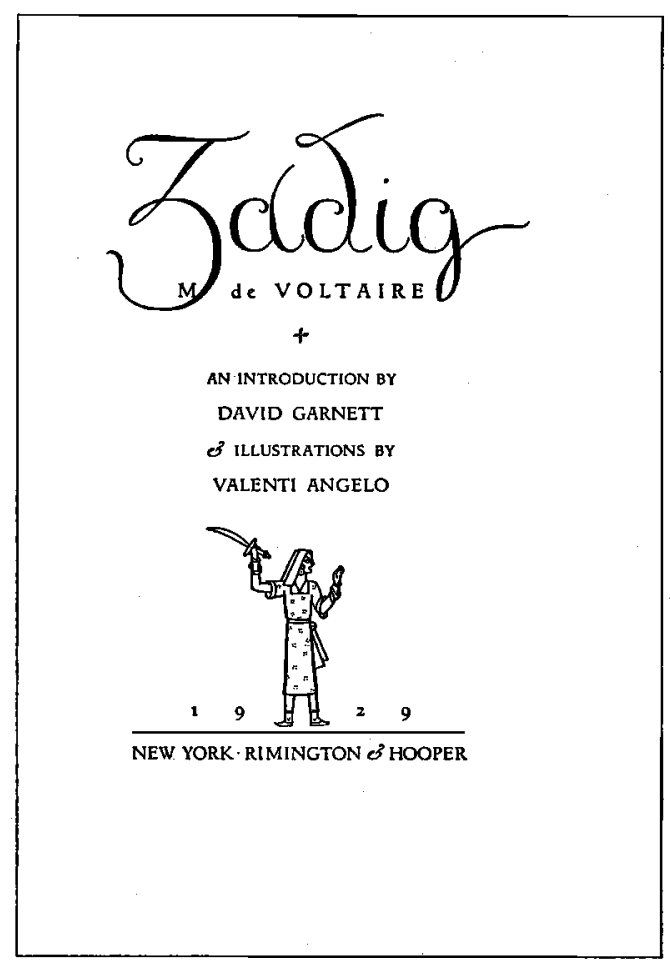


that Ellis never bungled. Mitchell Kennerley has said of Ellis: "Every piece he does, whether letterhead or folio volume, shows a knowledge of the fundamentals of literature and of types that expresses itself in a result that is both delightful and authentic. He has the surest touch of any book printer in America today."

Books poured out of Westport and booklovers poured in. Here Ellis and his wife worked in a partnership that was one of the greatest strengths of the Westport adventure. Mrs. Ellis contributed many ideas in the planning of books, learned to set type and became an old hand at "justifying the line," while, with equal competence, she would quit the composing room to act as hostess at an informal gathering or at one of the periodic literary teas for which the Georgian Press became known. Any day was open house for fellow printers, collectors, publishers and authors in the barn which for a century had housed

\section{THE INFERNO}

Canto i. Argument

The writer, having last his way in a gloomy forest, and being hindered by certain wild beasts from ascending a mounlain, is met by Virgil, who promises to show hin the punishments of Hell, and aflerwards of Purgalory; and that he shall then be cone dulted by Beatrice into Paradise. He follows the Roman poet.

IN the midwy of this our mortal life, (f) I f found me in a gloony wood, aftray Gone from my path direa: and e'en to tell, (3) It were no eary task, how savage wild Thas forest, bow robust and rough its growth, Which to remember only, my dismay

Renews, in bitrerness not far from death. Yet, to discourse of what there good befell, All else will I relate discover'd there.

How frost I enter'd it I scarce can say,

Such sleepy dullness in that instant weigh'd My sense down, when the true part I left;

But when a mountain's foot I reach'd, where closed

The valley that had pierced my heart with dread,

1 look'd aloft, and saw his shoulders broad

Already vested with that planet's beam,
The Inferno of Dante Aligbieri. Opening page of text, greatly reduced, but sbowing the type arrangement. Text composed by band in Caslon Old Style and Bell Italic. Initial in red. Printed from type on imported mouldmade paper for Cbesbire House. 
livestock and now had become one of the shrines of graphic arts in America. And there was no tedious repetition to the pattern of those days. In the early thirties RKO arranged to produce a screen version of Philip Barry's "The Animal Kingdom," and since part of the action centered in a printing-office, there was need to find a perfect model for the stage settings. The quest ended at the Georgian Press in Westport. Here, director Edward H. Griffith had Cameraman Wendell McRae shoot scenes of every room in the remodelled barn, while Richard Ellis tutored Leslie Howard in how a gentleman printer should handle type and tweezers. If you remember this motion picture you will recall that there was a scene when Leslie Howard straightened up from the proof press and there was a close-up of a title-page which, supposedly, he had composed. You have one guess as to who actually set that page.

Life at the Georgian Press was never dull. Another diverting moment was Ellis' first airplane flight with Christopher Morley to attend the dedication of the Lockwood Memorial Library at the University of Buffalo, an experience which Morley has made the subject of an essay in his book, Streamlines. "It had been my hope," Morley has written, "that four gentlemen, all bound for the opening of the Lockwood Library, might have travelled together by plane; they were respectively a publisher, a printer, a bookseller and a writer. For, had there been a crash, it would have been so perfect an opportunity for the obituaries to isolate a pure culture of the bacterium bibliopbile." Among R. E.'s treasures is a short poem which Morley pencilled on a scrap of paper while two miles up as a memento of their journey:

The printer of the Georgian Press, Above celestial wastes of cloud, Like most of us could not express This miracle by man endowed; But only said, with beaming face "Hereafter I will use more spaceAnd set my takes in upper case!"

The Chinese have an ancient saying that in books, as in life, an excess of sugar does not promote longevity. Those who visited the idyllic printing-office at Westport sometimes came away with the uneasy feeling that Ellis' house of books was too 
perfect to endure forever. The depression grew steadily worse during those early thirties; the overhead of running the Georgian Press began to exhaust available funds; and finally there came that grim afternoon in I933 when Richard Ellis locked the door of the remodelled barn and the Westport adventure which had been a brilliant, if too short chapter in the annals of American book-making was sadly concluded. Discouragement was a troublesome companion dogging Ellis's footsteps for a long time after that; more than years of apprenticeship, more than hour upon hour of patient, devoted toil had gone into those Westport days; into them also had gone the blind, boundless faith of creative enthusiasm. In the days, the weeks, the months which followed Richard Ellis thought often of Thoreau's remark: "Most men lead lives of quiet desperation." Everywhere he turned and looked the golden years of Westport still were so near, and yet so miserably far away.

\section{IV}

After Westport, factory-crowded Camden, New Jersey, certainly seemed a sad contrast when Ellis arrived there in 1935 . Its traffic-congested streets, its rows of dingy houses each built after the same plan, like so many cans of beans rolling out of the nearby Campbell factory, were not sights to stir a man's heart, and yet he remembered that there was romance haunting the byways of this ancient city. It had been to Camden that Walt Whitman had come by ferry from Philadelphia; there in the 70's and 80's Walt had pushed up the hill from the river, determination in every stride and a thirst for beer in his throat, and it was in Camden that tart old Walt had hounded the little job-printers with scraps of copy, glowering over their shoulders as they worked at the type-cases and howling constantly for his "slips." Camden to the literary man can never be a workaday conglomeration of factories, traffic and dirty houses; Camden is one of Walt's shrines, best preserved in his own vigorous lines:

I dream'd in a dream I saw a city invincible to the attacks of the whole rest of the earth,

I dream'd that was the new city of Friends,

Nothing was greater there than the quality of robust love, it led the rest, It was seen every hour in the actions of the men of that city.

And in all their looks and words. 
Just where Ellis, the horse and buggy printer, was to fit into the sprawling, modern, business-like plant of the Haddon Craftsmen here in Camden seemed a difficult conjecture. Yet here amid the roar of mighty presses, the daily pressure of production, of teletype messages from the New York office, and of the inescapable audition system which can call a man to the telephone from any corner of the plant, he set up a studio workshop and library where he could do the important work of a modern pioneer in bookmaking.

For the Ellis of Camden is the Ellis of Westport, with one revolutionary distinction. $\mathrm{He}$ is still the rugged individualist (if not an ideal pragmatist, then certainly a pragmatic idealist) who works when he pleases and as long as he pleases, who ignores the frantic teletypes and demands the time for thorough workmanship, who must supervise every line of proof and inspect every sheet from the press in spite of schedules and worried publishers, who must be given complete jurisdiction over every detail of a job, editorial and otherwise, if he is to touch it at all. He is still-yes, and he will always be-the young man in Lowdermilk's book store seeing the far horizons of printing. The revolutionary distinction is this: at Westport Ellis printed limited editions at sixty dollars a copy; at Camden the same unerring, painstaking craftsmanship is going in to editions of two hundred thousand or two hundred and fifty thousand copies at five dollars a copy.

In America today there is no more promising movement in printing. Because of it the trade book of the future will be a finer book; and the artist-printer, who was once more or less the exclusive property of the bibliophile with a fat bank roll, is becoming the willing servant of the whole fraternity of people who love books and who want to grace their library shelves with volumes which are an exciting adventure from the moment the hand touches them. Surely at Camden the credo of the early days of the Georgian Press is finding its richest fulfillment, and when this movement in the graphic arts reaches its full promise, the initials $\mathrm{R}$. E. will belong in the tradition of American printing as certainly as those of B. R. or F. W. G. The origins of the movement may be open to some dispute-being, in a sense, the sum total of the effort of each craftsman working for the advancement of book- 
making in America-still no informed student of the graphic arts can deny that in this year I94I Richard Ellis is its principal exponent.

Two of the volumes which Richard Ellis has supervised recently from his studio workshop in the plant at The Haddon Craftsmen will illustrate how the craft of the horse and buggy printer functions amid the boom-boom of modern production.

I. Leaves of Grass by Walt Whitman, a Book-of-the-Month Club dividend book published by Doubleday, Doran at five dollars. This superb volume, on which Ellis worked for many months, is quarto size and composed in I2-point Monotype Bodoni with specially cut long descenders. Paper for the book was specially made and the entire edition was printed on highspeed perfecting presses. Arrangements were made for an introduction by Christopher Morley and the illustrations, in full color by Lewis C. Daniel, were reproduced by lithography.

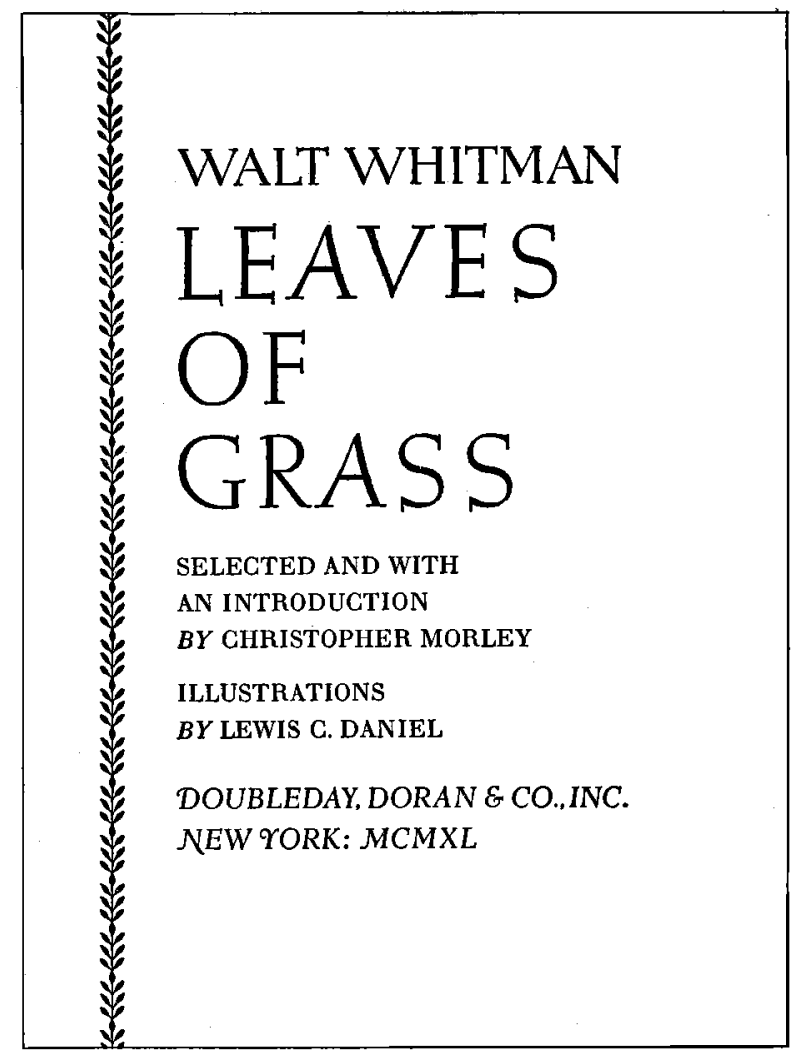

The text is composed in Monotype Bodoni witb long descenders. Printed from electrotypes on a macbine-made paper. Decoration on title page in green. 
II. Translations from the Cbinese by Arthur Waley, also a Book-of-the-Month Club dividend book published by Alfred A. Knopf, Inc., at five dollars. Two years of careful labor and research were consumed in planning and printing this magnificent edition. Once again, the paper was specially made under Ellis' supervision, this time to simulate old Chinese paper; the type is a special cutting of Goudy's Monotype Deepdene in a 16 -point size with revisions and swash characters drawn by R. E. with Goudy's approval (and with the understanding that the revised face will be reserved for Ellis' exclusive use). The volume is illustrated in color by Cyrus LeRoy Baldridge, who also collaborated with Ellis on the beautiful trade edition of The Adventures of Hajji Baba of Ispaban.

Limited editions produced by him at Haddon continue to reflect the flawless skill of the old Westport days. For Dr. A. S. W. Rosenbach he has in process in four folio volumes,

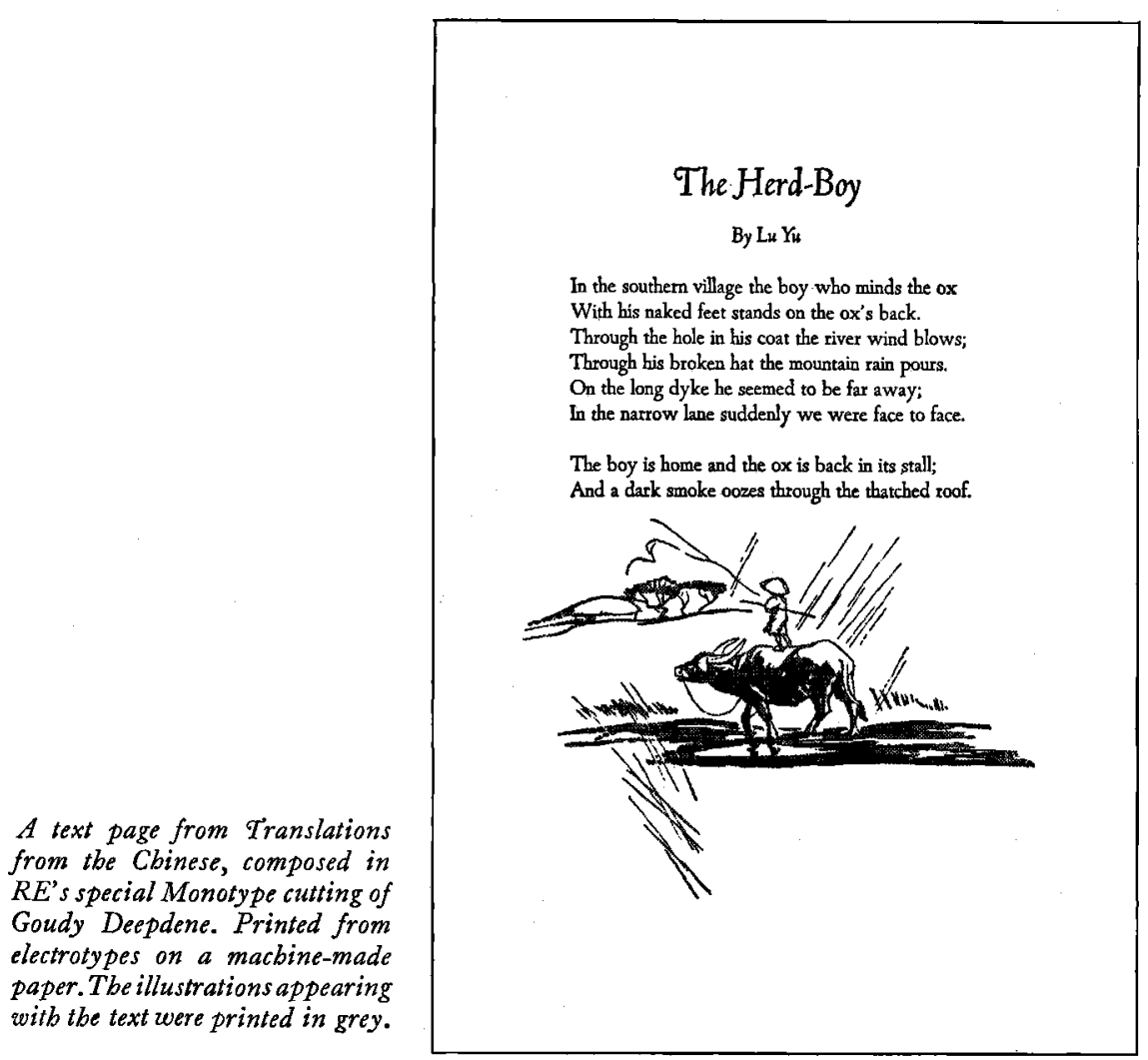


Tobacco, Its History Illustrated by the Books, Manuscripts and Engravings in the Library of George Arents, Fr., by Jerome E. Brooks in an edition of three hundred copies (list price, two hundred and sixty-five dollars a set); for the Free Library of Philadelphia he has done a sensitively executed catalogue, in large quarto, of the Fobn Frederick Lewis Collection of Medieval Manuscripts; and for William K. Vanderbilt, the handsomely printed, profusely illustrated Flying Lanes, an account of Mr. Vanderbilt's flight around South America and over the Andes.

Old Walt would have burst with pride if he could have seen the edition of Walt Wbitman in Camden (with an introduction by Christopher Morley) which Ellis edited and designed, and which The Haddon Craftsmen published for private distribution in 1938. Every detail of this volume reflects Ellis' mature skill as a printer-the cloth imported from Czechoslovakia for the binding, the deckle-edged, green tinted paper made in England, the beautifully composed pages in I2-point English Monotype Bell, the superb photographs by Arnold Genthe, the impeccable presswork. At the sight of the volume Walt would have grasped his hand and led him onto one of those gentlemanly debaucheries for which the old poet was so famous, doubtless with the result that the pair would have greeted the dawn somewhere around Germantown, both happier than a couple of larks.

Among the books which Ellis has planned, arranged in type, and supervised, and which Haddon Craftsmen have published for private distribution, are, in addition to Walt Wbitman in Camden, House-Warming and Winter Visitors by Henry David Thoreau (composed in Monotype Bell and bound in marble paper over boards), Three Essays by Ralph Waldo Emerson (with an appreciation by Van Wyck Brooks and a frontispiece and decorations by Vernon Sisson), The Affair at The Inn by Charles J. Finger (composed in a trial cutting of Monotype Janson, and illustrated by Cyrus LeRoy Baldridge), The Man Witbout a Country by Edward Everett Hale ("A wonderful revival of a wonderful story," President Roosevelt wrote to Ellis), and the present writer's own Composing Sticks and Mortar Boards, a discussion of university press printing.

As Goudy said of designing type-faces, "I just think of a letter and draw around it," so Richard Ellis plans a book- 
by thinking and building around it. His basic principle in book design is unanswerable: "I see no reason why the simple well printed type page should not have greater attraction for the reader than bizzare effects." And he will gamble a prediction: "Thinner books are coming-they need only the enthusiastic support of one leading publisher to have almost everyone else fall in line." He will tell you that though the first consideration in fine bookmaking is for craftsmanship in work-or, in short, for the paying of attention to little niceties-a practical printer must have the ability to work constructively and efficiently with the tools of modern book manufacturing, securing the desired result by careful preliminary preparation and constant supervision. A favorite axiom of Ellis' is: "Trifles make perfection, but perfection is no trifle." Again, he sees printing as a vocation of continual challenge: "The planning of books and any printed matter, whether a sumptuous volume or a postal card announcement, can call forth the full creative effort and

Tbe text is composed in English Monotype Baskerville. Printed from type on a macbine-made paper. Decorated rules and date on title page in terra-cotta red.

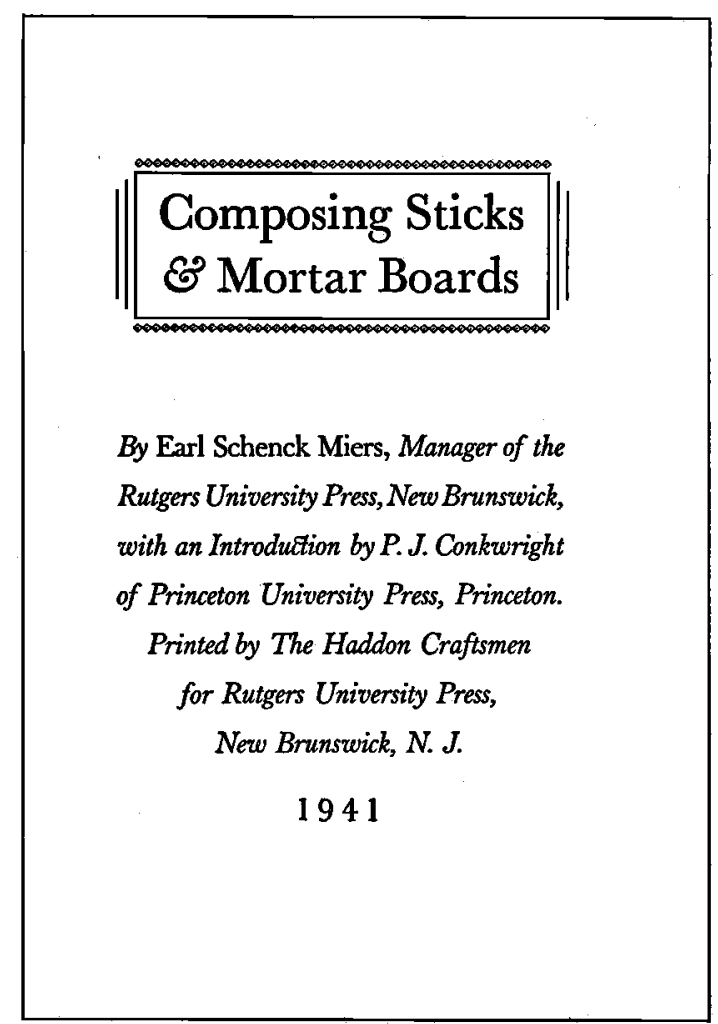


interest of the designer-printer, and give him happiness and success in his work."

The past six years at Camden have been happy, productive years for the horse and buggy printer, who is steadfast to his age by refusing to own an automobile (he travels by bus from his home in Moorestown, where his wife and three children have grown accustomed to his erratic hours). He works diligently over what old Walt called his "slips," and invariably he is swamped with detail. Now and then he turns his hand to literary production-there is his "Primer of Type" series, two numbers of which have appeared; his Five Hundred Years of Printing from Type, aptly dedicated "to those craftsmen of today and to those of tomorrow who will carry on the traditions of the noble art of printing"; and his sketches of famous booksellers on which he is now engaged. In addition to his studio workshop at Camden he has a study at home where he does a considerable part of his work, and so manages to keep

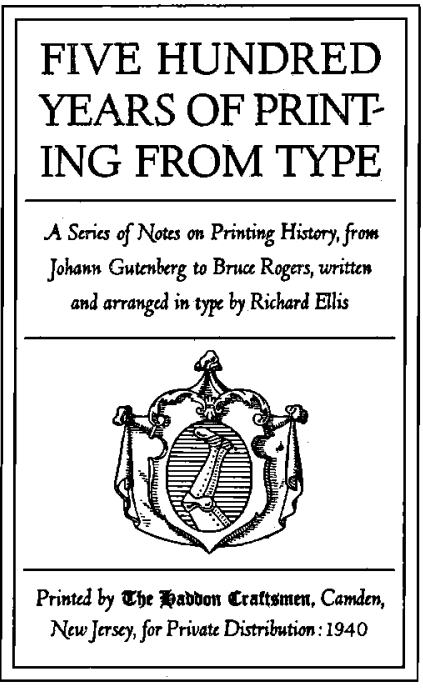

Text pages composed in various types characteristic of the printers discussed. Printed from type on rag paper. Rules and device on title page in terra-cotta red. 
his days and nights as busily occupied as during the years at Westport. As a member of the American Institute of Graphic Arts, the Art Alliance, the Typophiles (New York) and the Philadelphia Graphic Arts Forum, he is frequently on the hop, speaking, exhibiting his work, or discussing books. But his greatest fun is going back into the shop with the "boys," his eyes twinkling when they call his attention to a good piece of work, knowing that they have learned to share his enthusiasm for thorough craftsmanship so that even the trade books they produce without his direct supervision have a "touch" which can be traced to his influence. They call him a hard taskmaster, but they know that even though one shift may go off duty and another report, he will remain in the plant as long as the work needs him. At forty-seven Richard Ellis is in his prime with many of his best years ahead; it is a rich promise. He is the second "Poor Richard" from down Philadelphia way.

The text is composed in the special Monotype cutting of Goudy Deepdene. Printed from type on rag paper. Monogram on title page in grey-blue.

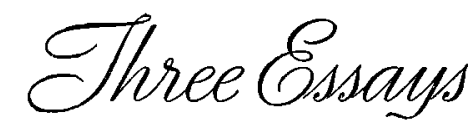

by Ralph Waldo Emerson

with An Appreciation by

Van Wyck Brooks

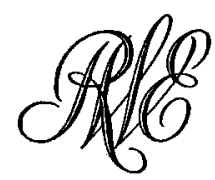

Camden: The Haddon Craftsmen Momxxxix 